\title{
What ARE The EFFECTS OF CONTAMINATION RISKS ON COMMERCIAL AND INDUSTRIAL PROPERTIES? EVIDENCE FROM BALTIMORE, MARYLAND.
}

\author{
By \\ Alberto Longo ${ }^{1}$ \\ Department of Economics and International Development \\ University of Bath \\ and \\ Anna Alberini \\ AREC, University of Maryland \\ and Fondazione Eni Enrico Mattei \\ Last revision: 6 September 2005 \\ Last Revision by: Anna Alberini
}

\begin{abstract}
Using the hedonic pricing approach, we investigate how the information released on public registries of contaminated and potentially contaminated sites affects nearby commercial and industrial properties in Baltimore, Maryland. We find that commercial and industrial properties are virtually unaffected by proximity to a site with a history of contamination. Knowing that the site is no longer considered contaminated does not have a rebound effect on property prices either.
\end{abstract}

We also find that urban economic development policies, such as Empowerment Zones and Enterprise Zones, have little effect on property values. In sum, brownfield properties in Baltimore are not particularly attractive investments for developers, and there is little potential for self-sustaining cleanup based on appropriate fiscal incentives, such as Tax Increment Financing. It is doubtful that "one size fits all" measures to encourage the cleanup of contaminated sites can be successful in this context.

JEL Classification: Q51, Q53, R33.

Key Words: Contaminated sites registries, Distance to Contaminated Sites, Hedonic Pricing Model, Brownfields.

\footnotetext{
1 Contact Author: Alberto Longo, Department of Economics and International Development, University of Bath, BA2 7AY, Bath, England, Telephone (+44) 1225 384508, Fax (+44) 1225 383423, e-mail A.Longo@bath.ac.uk. We wish to thank Shawn Bucholtz for his help with the construction of the dataset. The National Center for Smart Growth Research and Education at the University of Maryland provided financial support for this research.
} 


\section{What Are The Effects of Contamination Risks on Commercial and Industrial Properties? Evidence from Baltimore, Maryland.}

\section{Introduction}

A large body of literature documents the adverse effects of proximity to contaminated sites and environmental disamenities on the values of neighboring homes (Boyle and Kiel, 2001). By contrast, the economics literature on the effects of contamination on commercial and industrial properties is sparse, despite the broad implications of the contaminated site legislation in the US.

In the US, the Superfund law (1980) has been interpreted by the courts to impose strict liability for the cost of cleanup on the parties responsible for sites that pose risks to human health and ecological systems (Fogelman, 1992). Responsible parties are sought among the current owners and operators of contaminated properties. Many observers believe that, because of this provision, real estate developers and investors shun previously used properties, a problem compounded by the fact that lenders may deny investors loans for these properties.

Despite widespread efforts at the state level to encourage voluntary cleanups by offering liability and regulatory relief, and numerous state and federal brownfield initiatives, ${ }^{2}$ acquiring and redeveloping contaminated land continue to be problematic. There is still much concern that properties may become unattractive to developers because of existing or suspected contamination on the premises, or because of existing or suspected contamination on neighboring properties.

The recent Small Business Liability Relief and Brownfield Revitalization Act (2002), for example, spells out requirements that property owners must satisfy for availing themselves of the "third party causation" and the "innocent purchaser"

\footnotetext{
${ }^{2}$ Brownfields are "abandoned, idled or underused industrial and commercial properties where real or perceived contamination complicates expansion or redevelopment” (Simons, 1998).
} 
defense, which protects the owner from contamination that migrates to his or her property from someone else's property. Although the intent of this statute was to protect small businesses from the heavy burdens of the Superfund program and to expedite the cleanup and reuse of brownfields, some observers have expressed concern that its complexity may in the end spur more litigation and create new impediments to the redevelopment of brownfield properties (see, for example, Morford and Lifsey, 2002).

Some observers have also pointed out that many underused and potentially contaminated properties are located in economically blighted areas of cities (see, for example, Shutkin, 2000). Local and regional governments have often relied on fiscal policies and subsidies to stimulate growth in these areas.

In this paper we use the hedonic pricing model to investigate the effects of proximity to contaminated sites-or to sites that are merely suspected of contamination - and the effects of policies to stimulate growth in neglected areas on the value of commercial and industrial properties in Baltimore, Maryland.

Economic theory holds that the value of land is the discounted stream of net profits from that land. Contamination may enter in the determination of the land value through several channels: For example, it may reduce the sale price, reduce the purchase price, impose environmental remediation costs, and/or influence the productivity of economic activities on site.

We expect to see some or all of these effects influence the price of a contaminated property, but does the presence of contamination on this property influence the price of nearby commercial and industrial properties? It may if contaminants migrate to surrounding properties and foul nearby soil, water and airor the market fears that this may happen (Ihlanfeldt and Taylor, 2004). 
Public registries of contaminated sites can provide information on the hazardous effects of living near a contaminated property, but how valuable is this information for commercial and industrial activities? ${ }^{3}$ Are the values of commercial and industrial parcels affected by the presence or absence of contamination on nearby properties, to the point that owners might apply formal or informal pressures on the owners of neighboring properties to urge them to take precautions against releases of pollutants into the environment?

In principle, policies such as direct financial incentives or tax credits should boost investment in industrial and commercial areas where re-development can prove difficult, and in turn influence the value of these properties. But how much are the effects of these policies reflected on property prices, and can they offset the adverse effects of contamination or location close to contaminated sites?

This paper contributes to the debate on brownfields by investigating the above questions. We are particularly interested in understanding the effect of contamination risk on the value of adjacent properties. Our proxy for contamination risk is the placement of a parcel on an official registry of sites with known or suspected contamination, such as the CERCLA Information System and/or the State of Maryland's mini-superfund program database. We also wish to measure the impact on the prices of adjacent properties of a subsequent "no further action" recognition that there is no contamination on the premises.

\footnotetext{
${ }^{3}$ Decker et al. (2005) looked at the effects of the information provided by the Toxic Release Inventory (TRI) on housing prices in Omaha, Nebraska, and conclude that announcements about TRI pollutant emissions are significant determinants of residential housing values. In a different context, other authors have found that the release of information about the existence of pollution and a party's polluter status does have an effect on prices. For example, Konar and Cohen (1997) found that large TRI emitters realized significant company stock price declines on the day that those companies' TRI information was made public, and that those companies subsequently reduced TRI emissions to levels below their competitors. Khanna et al. (1998) found that repeated and persistent information on a firm's poor environmental performance, as measured by TRI releases, leads to statistically significant negative stock price returns.
} 
Focusing on commercial and industrial properties in Baltimore, we first check whether the proximity to a site recorded on the two official registries of (potentially) contaminated sites affects the value of nearby commercial and industrial properties. Second, we wish to see if property values rebound when a formerly contaminated site is cleaned up or a site that was thought to be contaminated is found to be clean. Third, we look at how two economic development policies, the State of Maryland Enterprise Zone (ENZ) Program and the federal Empowerment Zones (EMP) have affected commercial and industrial property values in Baltimore.

The answers to these questions should be valuable to policymakers seeking community support and/or funding mechanisms to finance the cleanup of contaminated properties. Both should depend crucially on the appreciation in value ensuing remediation and redevelopment, so it is important to find out if such appreciation truly occurs, and if it is aided by additional urban development policies.

We find that commercial and industrial property values in Baltimore city are virtually unaffected by the proximity to sites listed on-or de-listed from-registries of contaminated sites. We also find no evidence that urban development policies that offer tax credits for locating a business in a specified area in Baltimore City have increased the value of commercial and industrial real estate. We conclude that caution is needed when offering subsidies or other fiscal measures in Baltimore City to boost the development of neglected areas, because these are unlikely to result in increases in property prices. All policies and incentives will not be equally effective at all locations, a conclusion that sounds a common theme with Schoenbaum (2002).

The remainder of the paper is organized as follows. Section 2 reviews the literature on the effects of own and nearby contamination and of policies to stimulate the growth of neglected areas in inner cities. Section 3 presents the model and the data 
used for the analysis. Section 4 presents the results of the investigation of commercial and industrial properties in Baltimore city. We offer concluding remarks in section 5.

\section{Previous Literature}

\section{A. The Effect of Own Contamination}

In theory, contamination may affect several of the components of the profit of using land for commercial or industrial uses, which in turn influences the value of the property. In practice, how important are these effects for commercial and industrial properties, which often inherit contamination from previous owners?

It is not entirely clear whether the presence of contamination on or near a property slated for commercial or residential use affects its price. ${ }^{4}$ One reason why it is difficult to study this issue is that, as Jackson (2001a) notes, only recently have these properties begun to sell with any frequency. Alberini et al. (2004) survey US real estate developers themselves and find that they do not automatically assume that contaminated properties are priced less than comparable, but pristine, parcels. ${ }^{5}$

Simons and Sementelli (1997) compare sale prices of commercial properties with leaking underground storage tanks (LUSTs), properties with non-leaking tanks registered with the State of Ohio (RUSTs) and other commercial properties (baseline) in Cleveland for the years 1989-1992. Both LUST sites and RUST sites transact at significantly lower rates than the baseline commercial properties, but the prices of

\footnotetext{
${ }^{4}$ By contrast, when attention is restricted to housing prices, several studies have documented the negative effect of the proximity to contaminated sites on the sale prices of homes (Kohlhase, 1991; Reichert et al., 1991; Nelson et al., 1992; Smolen, Moore and Conway, 1992; Kiel and McClain, 1995; Kiel, 1995; Carroll et al., 1996; Dale et al., 1999; Simons, 1999). Boyle and Kiel (2001) survey studies that have used the hedonic pricing method to estimate the prices that households are willing to pay for environmental goods. Of these, 14 look at the distance to toxic or potentially toxic sites.

${ }^{5}$ When asked to express their agreement or disagreement with the statement "Contaminated properties have prices that are depressed relative to market potential," less than 1 percent of the respondents said that this "never" happens, $6.40 \%$ selected an intermediate response category between "never" and "sometimes," 39.73\% said "sometimes," 39.36 selected an intermediate category between "sometimes" and "always," and 16.84 opted for the "always" answer.
} 
RUST and LUST sites are not significantly different. Sementelli and Simons (1997) further find that removing a LUST from the registry of contaminated properties after remediation accompanied by a "no further action" letter from the State of Ohio does not improve transaction rates: Only $0.2 \%$ of the LUST sites sold after receiving the "no further action" letter. This is much lower than the $10 \%$ transaction rate for nontank commercial properties over the same period and the $4 \%$ rate for the LUST sites that did not receive a "no further action" letter.

McGrath (2000) examines the role of contamination risk on urban industrial redevelopment in the City of Chicago. Following Noonan and Vidich (1992), he represents contamination risk as the a priori probability of a parcel's contamination based on historical land use at the site, and finds that contamination impacts the probability that a previously used site is redeveloped both directly, and indirectly, via the differential in price before and after redevelopment. ${ }^{6}$

In one analysis, Jackson (2001b) finds that the prices of previously contaminated industrial properties in California are not adversely impacted relative to comparable but uncontaminated properties. In another, which covers 140 industrial property sales in Southern California in the period 1995-1999, Jackson (2002) finds that industrial contaminated properties sell at prices approximately $30 \%$ less than unimpaired levels. After the cleanup had occurred, prices recover to be indistinguishable from comparable uncontaminated properties.

Howland (2000) studies the impact of contamination on demand for and supply of industrial land in Baltimore City. Based on a survey that covers 69 percent of the industrial area, she concludes that documented land contamination is not

\footnotetext{
${ }^{6}$ McGrath's theoretical model assumes that land is redeveloped when its value in the redeveloped state is higher relative to its value in the current use. The empirical work models the probability that a commercial or industrial property is redeveloped as a function of the difference in the estimated value of a parcel in its redeveloped state and its current use.
} 
deterring buyers from purchasing land in the Canton/Southeast area of Baltimore City. Land purchases and redevelopment are occurring on larger parcels, where sellers are willing to lower their price to compensate for the risks and costs associated with owning a site with a history of contamination.

She reports that in the period between September 1995 and September 1996, brownfield sites sold for 55 percent of the price per acre of clean sites, and among brownfield sites, those that were truly contaminated were sold at prices that were, on average, $75 \%$ lower than the asking price. Although there is some evidence that business and land owners are reluctant to put parcels on the market, the problem does not appear widespread. Surprisingly, the City of Baltimore appears to be more reluctant to redevelop contaminated parcels than does the private sector.

In another area in Baltimore City-the industrial district known as Carroll Camden in southwest Baltimore-Howland (2002) finds that in the period 1990-2000 parcels with known contamination sold at a $67 \%$ discount and parcels with historical reasons to suspect contamination sold at an average $65 \%$ discount.

Based on interviews with real estate agents, Howland suggests that more important barriers to the revitalization of brownfields in Baltimore City are incompatible land uses, obsolescent road patterns, inadequate water, sewer and telecommunications infrastructure, and obsolete buildings. In our minds, this raises the question whether prices and redevelopment activities are sensitive to other policy variables that imply in-kind subsidies to developers or tax credits.

Schoenbaum (2002) focuses on non-residential parcels in Fairfield, a two square mile industrial area in Baltimore City. Comparison of brownfields to nonbrownfield properties to identify variations in assessed land value, vacancy, property 
turnover, and redevelopment over 1963-1999 suggests no evidence of an association between these measures of value or market performance and brownfield status. ${ }^{7}$

\section{B. The Effect of Nearby Contamination}

Simons, Bowen and Sementelli (1999) compare transaction rates of commercial properties near LUST sites with other commercial properties in Cleveland. They find that for properties adjacent to LUST sites the transaction rate is $2.7 \%$ per year versus $4.0 \%$ per year for all other properties, the difference being statistically significant. Next, they compare the incidence of seller financing, which is indeed higher for properties adjacent to LUST sites than for other properties. Finally, they look at sites with sales before and after the discovery of contamination. Based on an analysis of six such sales, Simons, Bowen and Sementelli (1999) conclude that the average diminution in value due to the contamination was from $28 \%$ to $42 \%$.

Ihlanfeldt and Taylor (2004) study the effects of proximity to hazardous waste sites on commercial and industrial properties. Using sales data for the period 19811998 in Atlanta, Georgia, they estimate separate property price gradients both before and after the hazardous waste sites were listed on the Georgia Environmental Protection Division's Hazardous Site Inventory (HSI) or on the CERCLIS database. ${ }^{8}$ They find that the announcement of contamination status generates significant negative externality effects on the values of nearby properties. In contrast, prior to the discovery of contamination, proximity to sites that were eventually listed has no influence on the price of surrounding properties. In all cases, the post-announcement gradient is steeper than the pre-announcement gradient.

\footnotetext{
${ }^{7}$ Schoenbaum considers brownfields only those parcels where the possibility of contamination is deemed a reasonable assumption based on the historical and current land use.

${ }^{8}$ See Section 3.B for details on CERCLIS.
} 
Ihlanfeldt and Taylor use the price gradients to examine tax-increment financing (TIF) ${ }^{9}$ as an option for funding the cleanup of contaminated sites. Estimates of the total value losses caused by many of the sites are sufficiently large relative to the cost of remediation to justify tax-increment financing as a clean-up option. In their study, Ihlanfeldt and Taylor do not control for other economic development policies.

\section{The Effect of Economic Development Incentives}

It is widely argued that contaminated properties are located in economically disadvantaged areas (Simons, 1998) and that incentives are needed to encourage their reuse. Wassmer and Anderson (2001) study the use of local economic development incentives within the Detroit metropolitan area, ${ }^{10}$ finding that only certain forms of local incentives, at certain times, exert the expected positive influence on the value of commercial and manufacturing property. For example, establishing a TIF authority or a downtown development authority district in the average city in the Detroit area increased the commercial value of properties during the study period. These findings are tied to issues related to the redistribution of economic activity from the core to the periphery in US metropolitan areas.

On their part, real estate developers claim that they are responsive to a broad range of inducements. In surveys in Europe (Alberini et al., 2005) and in the US

\footnotetext{
${ }^{9}$ Tax increment financing (TIF) is a subsidy originally intended to help redevelop areas that are deemed "blighted" or "distressed." Since the area in the district where TIF is going to be implemented is going to be redeveloped, that means property values will probably go up, and therefore property tax revenues will go up, based on higher assessments. When that increase happens, the property tax revenue from the TIF district is split into two streams. The first stream is pegged to the original property values before the redevelopment; that amount of tax continues to go to the city, county, school district and other taxing bodies as before. The second stream consists of the increase in taxes resulting from the new development and higher property values - the "tax increment." That stream is paid into a special fund used to subsidize some portion of the redevelopment in the TIF district. TIF subsidies may pay for new infrastructure, planning expenses, job training, career education, demolition or rehabilitation of buildings, cleanup at contaminated areas (LeRoy et al., 2002).

10 These include industrial development bonds, manufacturing and commercial property tax abatements, tax increment financing, and downtown development authorities.
} 
(Wernstedt et al., forthcoming) choice experiments reveal that developers can be attracted to contaminated sites by offering them subsidies, liability relief, and less stringent regulation. Prior experience with projects at contaminated sites matters, in the sense these incentives do not appeal to the same extent to all developers.

\section{Study Design, Data and Model}

\section{A. Locale of the Study}

We focus on industrial and commercial properties in Baltimore, Maryland, a city with an industrial past that has struggled to regain its economic foothold and has many contaminated properties. ${ }^{11}$ This should allow us to identify properties with contamination ranging from light to severe. In addition, we wish to compare the results of our research with Howland $(2000,2002)$ and Schoenbaum (2002), who also studied areas within Baltimore, and with Ihlanfeldt and Taylor (2004), who focused on the Atlanta area, which has experienced much recent growth.

We restrict attention to the arms-length sales of commercial and industrial properties in Baltimore City (US Census County 24510) documented in the Maryland Department of Planning's MDPropertyView from 1990 to 2000, and use these data to answer three key research questions. First, are property values influenced by the proximity to sites that are potentially contaminated sites-where site investigation and/or the cleanup process are still on-going - to the extent that these are correctly identified by their presence on official registries? Second, once these sites are no longer considered contaminated, do the values of neighboring properties rebound?

\footnotetext{
${ }^{11}$ The population of Baltimore population has steadily declined since World War II, when many people began leaving the city to move to the suburbs. The population of Baltimore has continued to declined over the last decades, decreasing from 786,775 in 1980 to 651,154 in 2000 . In 2003, the median household income in Baltimore City was $\$ 30.078$ and the percent of the residents below poverty line was $22.9 \%$. For comparison, the median household income in the entire state of Maryland was $\$ 52,868$ and the share of the population below poverty line $8.5 \%$. Over the decade from 1990 to 2000 , Baltimore lost 54,526 jobs, while the state of Maryland created 349.819 (http://www.fedstats.gov).
} 
Third, are commercial and industrial property prices affected by incentives and other development policies?

\section{B. Contamination Risk and Economic Development Policies}

To capture the effect of contamination risk, we focus on sites listed on federal or state registries of contaminated or suspect properties because "listing" a site is a public signal of the possible presence of contamination on the premises. The sites that are currently under investigation for possible contamination problems or are currently being cleaned up are (i) those on the US Environmental Protection Agency's CERCLA Information System (CERCLIS), ${ }^{12}$ and (ii) those on the State of Maryland List.

Some observers argue that listing a site in a contaminated site registry creates a "stigma" effect that remains present until the site has been removed from the list (Simons, 1999). Other observers have argued that the stigma effect persists even after a site is removed from the registry (Dybvig, 1992).

The stigma effect associated with listing a site in a registry of contaminated sites was apparently one important reason why the US Environmental Protection Agency (EPA) deleted about 25,000 sites from CERCLIS, its registry of contaminated or potentially contaminated sites, after it established that no further remedial action was needed. According to the EPA, many of these sites were not contaminated, had already been cleaned up under state programs, or were being cleaned up; still,

\footnotetext{
${ }^{12}$ A site is listed in CERCLIS when the US Environmental Protection Agency (EPA) receives information suggesting that a hazardous substance has been or may be released into the environment at that location. CERCLIS also contains sites that have been assessed or addressed by the Superfund Emergency Response program for emergency or time-critical cleanups. Being included in CERCLIS does not mean that the site has been marked for cleanup by the Superfund program, nor means that a hazardous substance has, in fact, been released there. What it does mean is that EPA needs to assess the site, determine whether it poses a risk to human health, and whether remediation is needed. Only sites that are assigned a hazard ranking score of 28.5 or higher are proposed for inclusion in the National Priorities List (NPL). This list currently contains roughly 1400 sites that are deemed the most egregious for the seriousness and extent of the contamination problem.
} 
potential developers were reluctant to get involved with them because they remained on EPA's database.

The sites where contamination was suspected but eventually ruled out, or truly existed but was subsequently cleaned up, are those labeled NFRAP (No Further Action Planned) from the CERCLIS Archives. ${ }^{13}$ Baltimore City has a total of 29 sites currently in CERCLIS, 16 in the State of Maryland mini-Superfund program registry of contaminated sites during the period 1990-2002, and 88 sites in the CERCLIS Archives.

In 1982 the State of Maryland Enterprise Zone (ENZ) Program was established as an economic development tool to stimulate job creation and business investment through the use of real property tax and employment tax credits in specific areas of the State. Enterprise Zones are designated areas in Baltimore City for which special tax incentives are available to industrial and commercial businesses that hire additional full time workers. To further stimulate economic growth, Baltimore City received a Federal Empowerment Zone (EMP) designation on December 21, 1994, to "foster sustained economic opportunity and promote community revitalization through employment tax credits, job training, and loan programs to assist community residents and businesses." The Baltimore EMP extends over 6.8 square miles, covering three separate areas of east, west, and south Baltimore, and containing over 70,000 people and 2,000 businesses. $^{14}$

\footnotetext{
${ }^{13} \mathrm{~A}$ site is deleted from the CERCLIS database for one of two possible reasons. Either an investigation has shown that the site is not truly contaminated, or the property was contaminated but has been subsequently cleaned up. When a site is removed from the CERCLIS database, it is recorded on the CERCLIS Archive. In 1995, the US EPA removed about 35,000 sites from CERCLIS, placing them in a separate archive, NFRAP, having determined that these sites were no longer considered a potential threat to human health.

${ }^{14}$ There are two additional government program that concern directly contaminated sites and brownfields. The first is the Maryland Voluntary Cleanup program, which was established in 1997 and provides a certificate of completion and release from liability once remediation has taken place and has been approved by the Maryland Department of the Environment (MDE). The VCP law also exempts lenders from liability at a property that has undergone voluntary cleanup. The second program is the
} 


\section{The Model}

We use the sale data to estimate the regression model:

$$
\begin{aligned}
\text { lprice }_{i}=\gamma_{0}+ & \mathbf{x}_{i} \gamma_{1}+L C E R \_ \text {dist }_{i} \gamma_{2}+L N F R_{-} \text {dist }_{\mathrm{i}} \gamma_{3}+N U M_{-} 500_{i} \gamma_{4}+ \\
& +E M P_{i} \gamma_{5}+E N Z_{i} \gamma_{6}+v_{i}
\end{aligned}
$$

where lprice $\mathrm{i}_{\mathrm{i}}$ is the $\log$ transformation of sale price (in 2000 dollars), $\mathbf{x}_{\mathrm{i}}$ is a vector of variables thought to influence property prices, and LCER_dist $\mathrm{i}_{\mathrm{i}}$ is the log distance to the nearest suspected site at the time of the sale, if the nearest site is on the CERCLIS database or on the State of Maryland mini-Superfund program registry of contaminated sites, and 0 otherwise. LNFR_dist $t_{i}$ is the log distance to the nearest site previously thought to be contaminated at the time of the sale, if the nearest site is on the CERCLIS Archive, and 0 otherwise. NUM_500, $\mathrm{EMP}_{\mathrm{i}}$ and $\mathrm{ENZ}_{\mathrm{i}}$ are additional controls, which we explain in more detail in sections 3.D and 3.E below.

\section{Hypotheses about Contamination Risk}

Using GIS software, for each property, at the time of the sale, we measure the distance to the closest site on (i) the union of CERCLIS and the State of Maryland's mini-Superfund program registry of contaminated sites, or (ii) the CERCLIS Archives. Let $d$ denote the distance from the property being studied to the closest site. We create the variable LCER_dist=ln(d) if the closest site is on (i), and 0 if the closest site is on (ii). The variable LNFR_dist is equal to $\ln (\mathrm{d})$ if the closest site on the the CERCLIS Archives, and zero if it is on CERCLIS. (We exclude from the analysis the

Brownfield Program, which is managed by the Department of Business and Economic Development. This program provides economic incentives, such as loans grants, and property tax credits to clean up and redevelop certain properties that are contaminated with oil or other hazardous substances, are located in economically disadvantaged areas, and are located in specified jurisdictions. In this paper, we are unable to examine the effects of these programs: Only one site on CERCLIS and 5 sites on the CERCLIS Archives participated in the VCP after 1997, and only four of the sales we examine occur at a property that underwent voluntary cleanup. 
24 sales of parcels on one of the three registries. Note that if a site was listed on a registry only after the present sale, we ignore it for the purpose of this calculation.)

In equation (1), the coefficient $\gamma_{2}$ captures the effect of proximity to a site listed on (i). If $\gamma_{2}$ is positive, it suggests that an increase of the distance from a (potentially) contaminated site increases property values. If it is equal to zero, proximity to a (potentially) contaminated site does not impact the value of surrounding properties. ${ }^{15}$

The coefficient $\gamma_{3}$ captures the effect of proximity to a de-listed site. We have no prior expectations on the sign of $\gamma_{3}$ : Prices may remain depressed even after cleanup or investigation have shown that the site is not a threat to public health and the environment - the so-called "stigma" effect $\left(\gamma_{3}>0\right)$. Dale et al. (1999) found that housing property values do rebound after cleanup, so that $\gamma_{3}$ may well be negative.

For a property, we can calculate the price change when the closest listed site is de-listed. This is given by the difference of the coefficients of listing and de-listing multiplied by distance of the site from the listed site:

$$
\text { Llprice }_{i}=\left(\gamma_{2}-\gamma_{3}\right) L C E R_{-} \text {dist }_{i} .
$$

If the distance to a contaminated site reduces the value of surrounding properties, but deleting a site from a registry of contaminated sites eliminates this effect, then $\gamma_{2}-\gamma_{3}=0$. If de-listing a site has no effect whatsoever on the value of nearby properties, then $\gamma_{3}=0$. This would be interpreted to mean that signaling that an area is not a threat to human health and the environment (through de-listing) does not help increase the value of surrounding properties. Finally, de-listing a site may raise the values of property values, without completely offsetting the initial loss of

\footnotetext{
${ }^{15}$ Because our sale data span the period from 1990 to 2002, we are unable to empirically examine any structural changes due to the passage of the Small Business Liability and Brownfield Revitalization Act, which was passed in 2002 .
} 
value that occurred with its listing: In this case, $\gamma_{2}-\gamma_{3} \geq 0$. It is also conceivable that $\gamma_{2}-\gamma_{3}<0$, i.e., the rebounding effect is more pronounced that the original depreciation.

Another variable measuring the extent of contamination in the neighborhood is NUM_500 , the number of contaminated or suspect sites within 500 meters from the property whose sale price is being studied. The coefficient $\gamma_{4}$ gives information on a "density effect." It tells us how the value of a property is influenced by the presence of an additional site that is contaminated or suspect, or was contaminated and has been cleaned up.

\section{E. Other Regressors}

When running hedonic pricing regressions on property values, some authors (Wieand, 1973; Bastian et al, 2002; Lynch and Lovell, 2002; Howland, 2002) use price per acre (or its log) as the dependent variable. We cannot do so because we have many missing observations for the acreage of a site. To circumvent this problem our dependent variable is the logarithm of price of the parcel. We must, of course, control for the size of the parcel, and we do so by creating a missing value dummy, recoding acreage to zero when it is missing, and entering both the recoded acreage variable and the indicator of a missing value in the right-hand side of the price equation.

Turning to the other independent variables, the vector $\mathbf{x}$ includes several continuous and dummy indicators capturing factors thought to affect the price of a parcel. We follow other authors in considering land use-commercial and industrial, 
and, if so, of what type-distance to the city center, etc. ${ }^{16}$ Descriptive statistics for these variables are given in table 1.

Finally, two variables, $\mathrm{EMP}_{\mathrm{i}}$ and $\mathrm{ENZ}_{\mathrm{i}}$, capture the effect of urban economic development policies. $\mathrm{EMP}_{\mathrm{i}}$ is a dummy variable that takes on the value of 1 if property $\mathrm{i}$ is within an Empowerment Zone and was sold after 1994, and 0 otherwise; $\mathrm{ENZ}_{\mathrm{i}}$ is a dummy variable that takes on a value of 1 if property $\mathrm{i}$ is within an Enterprise Zone, and 0 otherwise.

We have no a priori expectation on the signs of $\gamma_{5}$ and $\gamma_{6}$. In principle, one might expect these coefficients to be positive, in the sense that providing these incentives to developers and businesses should make properties more attractive. On the other hand, these designations may capture undesirable neighborhood characteristics that tend to depress property values, in which case these coefficients might be negative (or zero).

\section{F. Estimation strategy}

Estimating equation (1) is complicated by the fact that commercial and industrial properties are sold infrequently, and there is reason to believe that unobservable characteristics of the parcel influence both the frequency of its transaction and its price. Since a transaction is observed only when the reservation price of the seller is lower or equal to the transaction price, a sample consisting only of sold properties is affected by a sample selection problem (Gatzlaff and Haurin, 1998), which we address by adopting a two-step Heckman-type approach.

\footnotetext{
${ }^{16}$ For example, Sivitanidou (1994) and Sivitanidou and Sivitanides (1995) study the value of industrial and commercial sites in the Los Angeles metropolitan area. They claim that variations across space in industrial rents reflect spatial variations not only in productivity enhancing firm amenities, but also utility-bearing worker amenities and the local institutional constraints on the supply of industrial space or land. Dobson and Goddard (1992) examine commercial and industrial prices and rents in four UK regions for the period 1972-1987, concluding that they are sensitive to interest rates and residential property values in the neighborhood.
} 
Formally, we observe the sale of a property $i$ at time $t$ only if the profit from the sale is greater than the discounted sum of profits from keeping the property. Therefore, the net profits $\mathrm{y}^{*}$ from selling a property can be described by the equation (3) $y_{i t}^{*}=z_{i t} \delta+\eta_{i t}$,

where $z_{i t}$ is a vector of site characteristics and location attributes, and $\eta_{\text {it }}$ is the error term assumed to be i.i.d. standard normal. We only observe net profits when $y_{i t}^{*} \geq 0$, i.e., when a sale occurs. If the error terms in equation (1) and (2) are correlated $\left(E\left(\eta_{i t} \varepsilon_{i t}\right)=\sigma_{\eta \varepsilon} \neq 0\right)$, the OLS estimates of the coefficients in equation (1) are biased.

To avoid this problem, we introduce an indicator $y_{i t}$ that takes on a value of one if a sale occurs, and 0 otherwise. The expectation of price, conditionally on observing a sale, is:

$$
E\left(\text { lprice }_{i t} \mid y_{i t}=1\right)=E\left(\text { lprice }_{i t} \mid y_{i t}^{*} \geq 0\right)=\beta_{0}+\mathbf{W}_{i t} \gamma+\rho_{\eta \varepsilon} \frac{\varphi\left(\mathbf{z}_{i t} \delta\right)}{\phi\left(\mathbf{z}_{i t} \delta\right)}
$$

where $\mathbf{W}$ is a vector that subsumes all of the right-hand side variables of equation (1), $\gamma$ is the vector of their respective coefficients, $\varphi(\bullet)$ is the standard normal pdf and $\Phi(\bullet)$ is the standard normal cdf.

On appending an error term, equation (4) becomes a regression equation that can be estimated using a two-step procedure. In the first step, we estimate a probit equation where the dependent variable is $y_{i t}$ :

$$
E\left(y_{i t}=1\right)=\operatorname{Pr}\left(y_{i t}^{*} \geq 0\right)=\Phi\left(\mathbf{z}_{i t} \delta\right) .
$$

We use the probit coefficients to form an estimate of the inverse Mills' ratio in equation (4):

$$
\hat{\lambda}_{i t}=\frac{\varphi\left(\mathbf{z}_{i t} \hat{\delta}\right)}{\phi\left(\mathbf{z}_{i t} \hat{\delta}\right)},
$$


and include it in the right-hand side of the price equation. OLS estimation of this amended price equation gives unbiased estimates. Because the regression equation corresponding to (4) has heteroskedastic error terms, we use heteroskedasticity-robust standard errors to compute $t$ statistics for the coefficients.

\section{Results}

\section{A. Site Characteristics}

Data from the state of Maryland indicate that as of 2000 there were 10,993 commercial and industrial properties in Baltimore. Among these, 3,655 properties were sold in the period 1990-2000. We grouped these properties into five areas, four of which are located on or near the waterfront (Fairfield, Canton/Southeast Baltimore, Camden, and Baltimore Center), while the fifth is not on the waterfront and essentially captures the rest of Baltimore. (For comparison, Howland, 2000, 2002, studied Canton/Southeast Baltimore and Camden, and Schoenbaum, 2002, Fairfield.) Table 2 reports the number of sites and transactions for different actual current uses and for different areas of the city.

We analyze the data separately for the five areas because industrial and commercial activities do not appear to be evenly distributed throughout Baltimore, and because we suspect that the value of a property is influenced by being located in a specific district. Moreover, an F-test rejects the null of equal coefficients for the five areas $\left(\mathrm{F}_{15,4043}=53.46\right) .{ }^{17}$ Because of the relatively small sample sizes, however, we pool all parcels within each study area, but control for land use using dummies.

\footnotetext{
${ }^{17}$ Straszheim (1974) uses F-tests to show that real estate markets within cities are segmented. Michaels and Smith (1990) asked experts in the real estate market of Boston which segments they should use.
} 
We first look at the properties that were listed on, or de-listed from, the three registries for each area. Canton has a total of 40 such sites, Camden 26, Fairfield and Center have 15 sites each, and the rest of Baltimore 17.

The nearest listed site is, on average, 1,022 meters away for parcels in Camden, 437 meters away for parcels in Canton, 727 meters for Fairfield, and 3,010 meters for parcels in the Rest of Baltimore. The closest de-listed site at the time of a sale is, on average, 478 meters away from parcels in Camden, 780 meters in Canton, 671 meters in Fairfield, 468 meters in the City Center, and 1,465 meters in the Rest of Baltimore. $^{18}$

Table 3 shows the descriptive statistics for the variables used in the Baltimore City analysis. We do T-tests to compare the characteristics of sites that were and were not sold during the study period. Briefly, we find that (i) EMP-designated parcels are more heavily represented among the sales in Canton, Center, Fairfield and Rest of Baltimore; (ii) properties sold to Canton and Center tend have fewer potentially contaminated sites within 500 meters than the properties sold elsewhere; and (iii) in waterfront areas, sales occur primarily close to the city center.

\section{B. Determinants of Price}

Table 4 presents the results of the hedonic pricing models for the five areas of Baltimore City. All of these models implement the sample-selection correction detailed in section 3 .

The models show that the logarithm of the price of a site is generally positively associated with its size, except in the City Center and Rest of Baltimore, and negatively associated with the age of buildings on-site. The dummy for Building

\footnotetext{
${ }^{18}$ When a site was sold in the Center of Baltimore, the closest site at the time of the sale was never a site that was listed on the CERCLIS database or on the State of Maryland mini-Superfund program registry of contaminated sites.
} 
is significant only in the City Center, where the presence of a construction makes a site less valuable. Taken together, this suggests that commercial and industrial property values decrease as demolition costs increase.

Regarding land use, all the properties in our sample are slated as for industrial or commercial use. However, some of them are used for residential purposes or as offices even though their primary classification is for industrial and commercial use. The former are captured into the intercept, while offices are accounted for by a dummy. Two additional dummies are used to denote commercial and industrial parcels that are used exclusively for such purposes. The regression results indicate that properties used for commercial, industrial and office uses are sold for less than comparable properties with some residences.

The coefficient of the distance to the central business district has the expected sign, and is significant in the areas closer to the center of the city (Camden, Canton and Center). By contrast, distance to the city center is less important in the two areas located far from the central business district (the Rest of Baltimore and Fairfield). ${ }^{19}$

\section{The Effect of Contamination Risk}

Table 4 suggests that distance to a listed site (LCER_dist) has virtually no effect on prices. Proximity to a listed site is not an externality reflected in property prices, as is shown by the insignificant coefficients on LCER_dist. Distance to a delisted site does not matter either, at least in Camden, Canton and Fairfield.

\footnotetext{
${ }^{19}$ The variables related to the socio-economic characteristics of the census tract do not generally affect the price of properties, with the exception of (i) employment rate, which is positively associated with property prices in all areas but Canton, (ii) poverty rate, which has a negative effect only in Canton and in the Rest of Baltimore, and (iii) mean household income, which is positively associated with property prices in the center of the city and Fairfield.
} 
A clarification is necessary to interpret the regression results for Baltimore Center: there were no CERCLIS sites within this area at the time of the observed sales, so we cannot construct and include the regressor LCER_dist for this area. We construct LNFR_dist, and this variable enters in the regression with a positive sign. This may capture stigma effects, or simply other disamenities associated with proximity to the sites on the CERCLIS Archives.

The Rest of Baltimore regression suggests that properties are unaffected by proximity to a listed site, and yet for some reason values increase as we get closer to de-listed sites. Perusal of maps shows that these sites are for the most part located close to major roads, so it is possible that the coefficient on distance to de-listed site truly captures access.

F-tests reject the null hypothesis that the coefficients on LCER_dist and LNFR_dist are equal for Camden (F-test=10.63) and Fairfield (F-test=13.28), but not for Canton $(\mathrm{F}$-test $=0.01)$ and Rest of Baltimore $(\mathrm{F}=1.05)$. We reach the same conclusions when we test the null that both coefficients are identically equal to zero: We reject the null for Camden $($ F-test=5.32) and Fairfield (F-test=6.94), but not for Canton (F-test $=0.52)$ and Rest of Baltimore $(\mathrm{F}=1.93)$.

In sum, we find slightly different results in different areas of the city. In general, however, proximity to a listed site does not affect property values. Distance to a de-listed site also has negligible effects in most parts of Baltimore, except in the Center and in the Rest of Baltimore. However, while in the City Center the positive sign of the coefficient is likely to capture the effect of a less attractive area, for the Rest of Baltimore the negative sign of the coefficient is likely to pick the effect of access. 
For Baltimore Center and Rest of Baltimore, we can calculate the effect of the distance from a de-listed site. The elasticity of price with respect to distance from a de-listed site is equal to 0.3238 in the city centre and -0.0459 in the peripheral area.

Turning to NUM_500, we find that the coefficient of this variable is significant only in the Center of Baltimore. The negative sign suggests that an additional (potentially) contaminated property located within 500 meters from a site decreases the value of that site by $11.5 \%$. For the average site, this means a decrease in its value of roughly 314,000 US\$.

Given the ambiguous results we found in the analysis of the effect of the proximity to a (potentially) contaminated site, we checked whether the effect of the proximity to a contaminated site is influenced by the seriousness of the threat it poses. Therefore, we selected the three NPL sites in Baltimore City and examined the effect on surrounding properties. ${ }^{20} \mathrm{We}$ constructed several samples: (i) all commercial and industrial properties in Baltimore that were sold over 1990-2000, and (ii) properties located within two, three, or four kilometers from the NPL sites. ${ }^{21}$ The coefficients on distance to the three sites were always insignificant. We conclude that commercial and industrial property values are not influenced by the proximity to a NPL site in Baltimore City. Finally, we checked if the size (in acres) of a (potentially) contaminated site has an effect on the value of nearby properties, but we found no evidence of such an effect.

\footnotetext{
${ }^{20}$ CERCLIS documents that Baltimore City has had a total three final NPL sites: Chemical Metals Industries, which was proposed for the NPL in 1981 and a final removal action in 1998; the Kane \& Lombard Street Drums, which joined the NPL in 1986 and is still there; and 68th Street Dump/Industrial Enterprises, located just outside the border of the city, which was proposed to the NPL in 1999, and re-proposed in 2003, suggesting that as of recently the site is still considered a threat to public health and environment. There are no other NPL sites in Baltimore County, the county surrounding Baltimore city.

${ }^{21}$ Kohlhase (1991) finds that the impact of contamination extends as far as 6 miles from the source. Ihlanfeldt and Taylor (2004) limit the analysis of the welfare change caused by contaminated sites within a 1.5 mile radius from the source of contamination.
} 


\section{Zone Designations}

Our results also suggest that the policy instruments used in Baltimore City to stimulate economic growth have different results in different parts of the city.

In general, property values do not seem to be affected by the urban economic development policies we examined. Property values are influenced by EMP or ENZ designation only in the Center of Baltimore. In this area, the coefficient for the ENZ designation is negative and significant, suggesting that even though businesses that locate in these areas are eligible for tax credits, these areas are still considered less valuable for commercial and industrial activities. When we look at the EMP designation in the Center of Baltimore, properties that sold after 1994 in an EMP zone experienced price increases, suggesting that the effects of EMP designation have positively affected property values in the city center.

These results suggest that the designation of EMP has been effective in stimulate business activities - and hence property values - in the City center, but not in other parts of Baltimore, and that other policies may be required to encourage development through increases in property values.

\section{Conclusions}

We have found that the value of an industrial or commercial property in Baltimore depends on several characteristics, such as the dimension of the parcel, the type of activity and land use, the location of the parcel, the presence of buildings and their age, and the socio-economic characteristics of the census tract where the site is located.

It is sometimes speculated that the value of a parcel slated for commercial or industrial uses is influenced by the proximity to a contaminated site, much like 
residential property values are often found to be negatively affected by proximity to Superfund sites or other environmental disamenities. Ihlanfeldt and Taylor (2004) have found evidence of such an effect in Atlanta, a city with much recent growth but relatively few contaminated sites, so one natural question is whether the same effect is detected in Baltimore, a city that has experienced loss of population and of its manufacturing base in recent decades and has many sites that are contaminated or suspect.

Our hedonic pricing models, however, find that proximity to a site listed on a registry of (potentially) contaminated properties or to one that was de-listed from such a registry has little impact on the value of commercial or industrial properties. Specifically, we find no distance effect in the western and southern parts of the city (Camden, Fairfield and Canton). For the Center of Baltimore, where no sale has occurred near listed sites, we find that property prices increase with the distance from a de-listed site, while in the Rest of Baltimore it would seem that moving away from de-listed sites actually increases values. However, interpretation of the results for the Center and for the Rest of Baltimore is complicated in the former area by the lack of sites on the registries of potentially contaminated properties, and in the latter by the likelihood that distance to de-listed sites captures access.

Our results confirm the findings by Howland (2000, 2002): The proximity to a contaminated or suspected to be contaminated property has little, if any, effect on the value of a parcel in Baltimore City. Our results also confirm the findings by Schoenbaum (2002): Policies aimed at enhancing economic growth have had little impact on property values in Baltimore city. Only in the Center of Baltimore does the EMP designation appear to have an effect. 
While we find little empirical evidence of the effects of listing and de-listing on the value of surrounding properties in Baltimore city, Ihlanfeld and Taylor (2004) do find evidence that listing negatively impacts property values in Atlanta.

One possible reason for our different results is that the effects of listing onand de-listing from - a registry of (potentially) contaminated sites depends on the characteristics of the real estate market. Clearly, Atlanta and Baltimore are different cities, both in terms of contamination and of economic activities and growth. We wholeheartedly agree with Ihlanfeldt and Taylor that their "results are specific to Atlanta, and care should therefore be taken in applying them to other areas" (Ihlanfeldt and Taylor, 2004, p. 133).

Our study bears on the issue of how valuable the information released on the public registries of contaminated properties is. For example, Boyd, Harrington, and Macauley (1996) argue that it is not the environmental liabilities themselves that predominantly distort real estate markets, but rather information asymmetries between buyers and sellers regarding the extent of contamination. However, the evidence from Baltimore suggests that raising awareness about possible contamination, or ruling out that a property might be contaminated, does not penalize neighboring properties in terms of price. Perhaps prices of industrial and commercial property already incorporate a "discount" for the possible presence of contamination and the vicinity to suspect sites that is not dispelled when a site is listed (or de-listed) on registries that can be easily consulted by the public.

Taken together with the results in Howland $(2000,2002)$ and Schoenbaum (2002), our work has a number of interesting and potentially important implications. The first is that at certain locales there would seem to be little to gain for a developer from acquiring contaminated properties or properties near brownfields: In Baltimore, 
these properties are no cheaper than other commercial and industrial properties. Second, there is also little incentive for a developer to clean up contaminated properties, since this property and neighboring properties do not appear to experience increases in values. Third, based on our results, we surmise that any informal pressure by neighbors on a property or business owner to take care and avoid contamination on the premises is unlikely to be effective: Nearby owners would not be able to claim that they suffer losses in value due to the presence of nearby contamination, and would not experience appreciation in the event that a contaminated site is remediated. Fourth, there is little potential in Baltimore for public financing schemes for cleanup based on appreciation of property values (e.g., TIF), because property values and revenues would not increase as a result of the cleanup.

In sum, we find that the information contained in publicly accessible registries of contaminated sites has not had much of an effect on commercial and industrial properties in Baltimore. Economic development initiatives intended to attract business do not influence property prices either, suggesting that "one size fits all" prescriptions for encouraging environmental remediation and redevelopment through increases in values are unlikely to work at all locales, and that policies may have to be devised based on local conditions. 


\section{References}

Alberini, A., A. Longo, S. Tonin, F. Trombetta, M. Turvani (2005) "The Role of Liability, Regulation and Economic Incentives in Brownfield Remediation and Redevelopment: Evidence from Surveys of Developers," Regional Science and Urban Economics, 35(4), 327-351.

Alberini, Anna, Peter B. Meyer, and Kris Wernstedt (2004), "Policies for Cleanup and Reuse of Contaminated Sites: Evidence from a Survey of US Real Estate Developers," paper presented at the annual EAERE Meeting, Budapest, June.

Bastian, C.T. D.M McLeod, M.J. Germino, W.A. Reiners and B.J. Blasco (2002), "Environmental Amenities and Agricultural Land Values: A Hedonic Model Using Geographic Information Systems Data," Ecological Economics, 40(3), 337-349.

Boyd, J., Harrington, W. and M. Macauley (1996) "The Effects of Environmental Liability on Industrial Real Estate Development," Journal of Real Estate Finance and Economics, 12(1), 37-58.

Boyle, M. and K.A. Kiel (2001), "A Survey of House Price Hedonic Studies of the Impact of Environmental Externalities," Journal of Real Estate Literature, $9(2), 117-144$.

Carroll, T.M., T.M. Clauretie, J. Jensend and M. Waddoups (1996), "The Economic Impact of a Transient Hazard on Property Values: The 1988 Pepcon Explosion in Henderson, Nevada," Journal of Real Estate Finance and Economics, 13(2), 143-167.

Dale, L., J.C. Murduch, M.A. Thayer and P.A. Waddell, (1999), "Do Property Values Rebound from Environmental Stigmas? Evidence from Dallas," Land Economics, 75(2), 311-326.

Decker, C.S., D.A. Nielsen, and R.P. Sindt (2005) "Residential Property Values and Community-Right-to-Know-Laws: Has the Toxics Release Inventory had an Impact?," Growth and Change, 36(1): 113-133.

Dobson S.M. and J.A. Goddard (1992), "The Determinants of Commercial Property Prices and Rents," Bulletin of Economic Research, 44(4), 301-321.

Dybvig, L.O. (1992), "Contaminated Real Estate Implications for Real Estate Appraisers," The Research and Development Fund, Appraisal Institute of Canada.

Fogelman, V.M. (1992), "Hazardous Waste Cleanup, Liability, and Litigation: A Comprehensive Guide to Superfund Law." Westport, CT: Quorum.

Gatzlaff, D.H. and D.R. Haurin (1998), "Sample Selection and Biases in Local House Value Indices," Journal of Urban Economics, 43, 199-222. 
Howland, M. (2000), "The Impact of Contamination on the Canton/Southeast Baltimore Land Market," Journal of the American Planning Association, 66(4), 411-420.

Howland, M. (2002), "The Legacy of Contamination and the Redevelopment of Inner-City Industrial Districts," National Center for Smart Growth Research Paper, July.

Ihlanfeldt, K.R., and L.O. Taylor (2004), "Externality Effects of Small-Scale Hazardous Waste Sites: Evidence from Urban Commercial Property Markets," Journal of Environmental Economics and Management, 47(1), 117-139.

Jackson, T.O. (2001a), "The Effect of Contamination on Real Estate: A Literature Review," Journal of Real Estate Literature, 9(2), 93-116.

Jackson, T.O. (2001b), "The Effects of Previous Environmental Contamination on Industrial Real Estate Prices," The Appraisal Journal, 69(2), 200-10.

Jackson, T.O. (2002), "Environmental Contamination and Industrial Real Estate Prices," Journal of Real Estate Research, 23(1-2), 179-199.

Khanna, M., W.R.H. Quimio, and D. Bojilova (1998) "Toxic release information: A policy tool for environmental protection," Journal of Environmental Economics and Management 36: 243-266.

Kiel, K.A. (1995), "Measuring the Impact of the Discovery and Cleaning of Identified Hazardous Waste Sites on House Values," Land Economics, 71(4), 428-435.

Kiel, K.A., and K.T. McClain (1995), "House Pricing During Siting Decision Stages: The Case of an Incinerator from Rumor through Operation," Journal of Environmental Economics and Management, 28(2), 241-255.

Konar, S., and M.A. Cohen (1997) "Information as regulation: The effect of community right to know laws on toxic emissions," Journal of Environmental Economics and Management 32: 109-124.

Kohlhase, J.E. (1991), "The impact of toxic waste sites on housing values," Journal of Urban Economics, 30(1): 1-26.

LeRoy, G., S. Hinkley, P. Mattera, M. Khan, C. Brown, K. Davis, and R. Heck (2002), "No More Secret Candy Store: A Grassroots Guide to Investing Development Subsidies," Good Jobs First, Washington DC, downloadable at http://www.goodjobsfirst.org/research.htm.

Lynch, L and S.J. Lovell (2002), "Hedonic Price Analysis of Easement Payments in Agricultural Land Preservation Programs," Working Paper Department of Agricultural and Resource Economics University of Maryland 02-13.

McGrath, D.T. (2000), "Urban Industrial Land Redevelopment and Contamination Risk," Journal of Urban Economics, 47(3), 414-442. 
Michaels, R.G. and V.K. Smith (1990), "Market Segmentation and Valuing Amenities with Hedonic Models: The Case of Hazardous Waste Sites," Journal of Urban Economics, 28(2), 223-242.

Morford, Mark J. and Margi C. Lifsey (2002), "SABRA Reshapes CERCLA Liability," Oregon Insider, 291, March 1, available at www.stoel.com/resources/articles/environment/env_020.shtm

Nelson, A.C., J. Genereux, and M. Genereux (1992), "Price Effects of Landfills on House Values," Land Economics, 68(4), 359-65.

Noonan, F. and C.A. Vidich (1992), "Decision analysis for utilizing hazardous waste site assessments in real estate acquisition," Risk Analysis, 12(2), 245-251.

Reichert, A., M. Small, and S. Mohanty (1991), "The impact of landfills on residential property values," The Journal of Real Estate Research, 7, 297-314.

Schoenbaum, M. (2002), "Environmental Contamination, Brownfields Policy, and Economic Redevelopment in an Industrial Area of Baltimore, Maryland," Land Economics, 78(1):60-71.

Sementelli, A. J. and R. A. Simons (1997), "Regulation of Leaking Underground Storage Tanks: Policy Enforcement and Unintended Consequences," Economic Development Quarterly, 11(3), 236-48.

Shutkin, William A. (2000), The Land that Could Be. Environmentalism and Democracy in the Twenty-First Century, Cambridge, Mass.: MIT Press.

Simons, R.A. (1998), Turning Brownfields into Greenbacks. Developing and Financing Environmentally Contaminated Urban Real Estate, Washington, DC: Urban Land Institute.

Simons, R.A. (1999), "The Effect of Pipeline Ruptures on Noncontaminated Residential Easement-Holding Property in Fairfax County," The Appraisal Journal, 67(3), 255-263.

Simons, R. A., W. M. Bowen, and A. J. Sementelli (1999), "The Price and Liquidity Effects of UST Leaks from Gas Stations on Adjacent Contaminated Property," The Appraisal Journal, 67(2), 186-94.

Simons, R. A., and A. J. Sementelli (1997), "Liquidity Loss and Delayed Transactions with Leaking Underground Storage Tanks," The Appraisal Journal, 65(3), 255-60.

Sivitanidou R. (1994), "Urban Spatial Variations in Office - Commercial Rents: the Role of Spatial Amenities and Commercial Zoning," Journal of Urban Economics, 38(1), 23-49.

Sivitanidou R., and P. Sivitanides (1995), "Industrial Rent Differentials: The Case of Greater Los Angeles,” Environment and Planning, 27(7), 1133-1146. 
Smolen, G.E., G. Moore, and L.V. Conway (1992), "Economic Effects of Hazardous Chemical and Proposed Radioactive Landfills on Surrounding Real Estate Values," The Journal of Real Estate Research, 7(3), 283-295.

Straszhaim, M. (1974), "Hedonic Estimation of Housing Market Prices: A Further Comment," Review of Economic and Statistics, 56(3), 404-406.

US GAO (1995), "Community Development--Reuse of Urban Industrial Sites," GAO/RCED-95-172. Washington, DC: USGPO.

Wassmer R. W., and J.E. Anderson (2001), "Bidding for Business: New Evidence on the Effect of Locally Offered Economic Development Incentives in a Metropolitan Area," Economic Development Quarterly, 15(2), 132-148.

Wernstedt, Kris, Peter Meyer, Anna Alberini, and Lauren Heberle (forthcoming), "Incentives for Private Residential Brownfields Development in U.S. Urban Areas," Journal of Environmental Planning and Management.

Wieand, K.F. (1973), “Air Pollution and Property Values: A Study of the St. Louis Area," Journal of Regional Science, 13(1), 91-95. 
Table 1. Description of the variables used in the analysis

\begin{tabular}{|ll||}
\hline Variable name & Description \\
\hline \hline Lprice & Natural logarithm of sale price \\
Lacres & Natural logarithm of acres \\
Acresmiss & Dummy variable equal to 1 if there is no information on the acreage of a site, 0 otherwise \\
Building & Dummy variable equal to 1 if the site has a building, 0 otherwise \\
Age & Age of the building at the site \\
Agemiss & Dummy variable equal to 1 if there is no information on the age of the building, 0 otherwise \\
Industrial & Dummy variable equal to 1 if the site is used for industrial purposes, 0 otherwise \\
Offices & Dummy variable equal to 1 if the site is used offices, 0 otherwise \\
Apartments & Dummy variable equal to 1 if the site is used for apartments, 0 otherwise \\
Commercial & Dummy variable equal to 1 if the site is used for commercial activities, 0 otherwise \\
Poverty & Percentage of people below the poverty line in the census tract for Baltimore City and in the \\
Hhinc & zip code for Maryland \\
Employed & Mean household income in the census tract for Baltimore City, in the zip code for Maryland \\
Lcbd_dist & Percentage of employed in the census tract \\
& Natural logarithm of the distance to the Central Business District \\
LCER_dist & logarithm of the distance to the nearest site at the time of the sale, if the nearest site is on the \\
& CERCLIS database or on the State of Maryland mini-Superfund program registry of \\
LNFR_distj & contaminated sites, and 0 otherwise \\
& logarithm of the distance to the nearest site at the time of the sale, if the nearest site is on the \\
NUM_500j & CERCLIS Archive, and 0 otherwise \\
& Number of sites with a history of contamination (listed, de-listed, not listed at the time of the \\
EMP & sale of site j) within a 500 meter radius distance from site $j$ \\
ENZ & Dummy variable equal to 1 if a site has been sold after 1994 and is located within an \\
Empowerment Zone, 0 otherwise
\end{tabular}


Table 2. Commercial and Industrial properties in Baltimore City. In parenthesis are the number of sites that have been sold in the period 1990-2000

\begin{tabular}{|c|c|c|c|c|c|c|}
\hline & \multicolumn{4}{|c|}{ Bay Area } & \multirow{2}{*}{$\begin{array}{c}\text { Rest of } \\
\text { Baltimore }\end{array}$} & \multirow{2}{*}{$\begin{array}{c}\text { Baltimore } \\
\text { city }\end{array}$} \\
\hline & Camden & Canton & Fairfield & Center & & \\
\hline \multirow{2}{*}{ Offices } & 127 & 159 & 30 & 725 & 385 & 1,426 \\
\hline & (40) & (51) & (10) & (231) & (161) & $(463)$ \\
\hline \multirow{2}{*}{ Industrial } & 144 & 188 & 59 & 49 & 114 & 554 \\
\hline & $(50)$ & (67) & (18) & (16) & (29) & (177) \\
\hline \multirow{2}{*}{ Apartments } & 188 & 309 & 134 & 472 & 728 & 1,831 \\
\hline & (39) & $(176)$ & (11) & (202) & (188) & (616) \\
\hline \multirow{2}{*}{ Commercial } & 1,291 & 1,815 & 230 & 1,738 & 2,108 & 7,182 \\
\hline & (411) & (564) & (78) & $(662)$ & (684) & $(2,399)$ \\
\hline Total sites & 1,750 & 2,471 & 453 & 2,984 & 3,335 & 10,993 \\
\hline Total transactions & $(540)$ & $(858)$ & $(117)$ & $(1,108)$ & $(1,062)$ & $(3,655)$ \\
\hline
\end{tabular}


Table 3. Descriptive statistics of sold properties in Baltimore City

\begin{tabular}{|c|c|c|c|c|c|c|c|c|c|c|}
\hline & Camd & & Cantor & & Fairfic & & Cente & & $\begin{array}{r}\text { Rest } \\
\text { Baltim }\end{array}$ & \\
\hline & $\begin{array}{l}\text { Sample } \\
\text { Average }\end{array}$ & Obs. & $\begin{array}{l}\text { Sample } \\
\text { Average }\end{array}$ & Obs. & $\begin{array}{l}\text { Sample } \\
\text { Average }\end{array}$ & Obs. & $\begin{array}{l}\text { Sample } \\
\text { Average }\end{array}$ & Obs. & $\begin{array}{l}\text { Sample } \\
\text { Average }\end{array}$ & Obs. \\
\hline Price & 510,638 & 2540 & $\begin{array}{l}1,103,442 \\
\end{array}$ & 858 & $7 \overline{770,361}$ & 117 & $2,731,310$ & 1,108 & 564,086 & 1,032 \\
\hline Acres & 0.88 & 506 & 0.54 & 278 & 1.67 & 110 & 0.20 & 302 & 0.69 & 119 \\
\hline Acresmiss & 0.06 & 540 & 0.67 & 858 & 0.05 & 117 & 0.72 & 1,108 & 0.88 & 1,032 \\
\hline Building & 0.71 & 540 & 0.78 & 858 & 0.87 & 110 & 0.44 & 302 & 0.84 & 119 \\
\hline Age & 73 & 386 & 74.5 & 219 & 55.8 & 96 & 75.2 & 143 & 56.2 & 104 \\
\hline Agemiss & 0.12 & 540 & 0.07 & 858 & 0.12 & 117 & 0.14 & 1,108 & 0.01 & 1,032 \\
\hline Employed & 0.90 & 540 & 0.89 & 858 & 0.86 & 117 & 0.93 & 1,108 & 0.91 & 1,032 \\
\hline Poverty & 0.25 & 540 & 0.22 & 858 & 0.25 & 117 & 0.27 & 1,108 & 0.20 & 1,032 \\
\hline Hhinc & 28,013 & 540 & 28,099 & 858 & 23,988 & 117 & 30,624 & 1,108 & 30,845 & 1,032 \\
\hline LCBD_dist & 7.15 & 540 & 6.86 & 858 & 6.13 & 117 & 6.56 & 1,108 & 8.52 & 1,032 \\
\hline $\begin{array}{l}\text { LCER_dist } \\
\text { (all obs.) }\end{array}$ & 1.84 & 540 & 0.37 & 858 & 0.16 & 117 & 0 & 1,108 & 2.12 & 1,032 \\
\hline $\begin{array}{l}\text { LCER_dist } \\
\text { (no zero obs.) }\end{array}$ & 6.72 & 148 & 6.08 & 53 & 6.59 & 3 & 0 & 1,108 & 8.01 & 308 \\
\hline $\begin{array}{l}\text { LNFR_dist } \\
\text { (all obs.) }\end{array}$ & 4.42 & 540 & 6.13 & 858 & 6.51 & 117 & 6.15 & 1,108 & 4.87 & 1,032 \\
\hline $\begin{array}{l}\text { LNFR_dist } \\
\text { (no zero obs.) }\end{array}$ & 6.17 & 392 & 6.66 & 805 & 6.68 & 114 & 6.15 & 1,108 & 7.29 & 724 \\
\hline NUM_500 & 1.53 & 540 & 1.09 & 858 & 0.17 & 117 & 1.13 & 1,108 & 0.10 & 1,032 \\
\hline EMP & 0.07 & 540 & 0.11 & 858 & 0.17 & 117 & 0.22 & 1,108 & 0.01 & 1,032 \\
\hline ENZ & 0.62 & 540 & 0.27 & 858 & 0 & 117 & 0.40 & 1,108 & 0.31 & 1,032 \\
\hline
\end{tabular}


Table 4. Hedonic models for properties in Baltimore City, dependent variable is logarithm of price, heteroskedasticity-robust T-statistics in parenthesis.

\begin{tabular}{|c|c|c|c|c|c|}
\hline & Camden & Canton & Fairfield & Centre & $\begin{array}{c}\text { Rest of } \\
\text { Baltimore }\end{array}$ \\
\hline \multirow[t]{2}{*}{ Intercept } & 9.7998 & 19.5927 & 10.6977 & 8.9503 & 7.2301 \\
\hline & $(4.62)$ & $(10.66)$ & $(4.73)$ & $(4.65)$ & $(2.58)$ \\
\hline \multirow[t]{2}{*}{ Lacres } & 1.2248 & 0.8742 & 1.4013 & -0.0024 & 0.4644 \\
\hline & $(9.06)$ & $(5.59)$ & (8.19) & $(-0.01)$ & $(0.90)$ \\
\hline \multirow[t]{2}{*}{ Acresmiss } & 0.4489 & -0.1908 & 5.6396 & -1.1653 & -0.6711 \\
\hline & (1.59) & $(-0.81)$ & $(2.82)$ & $(-3.96)$ & $(-1.32)$ \\
\hline \multirow[t]{2}{*}{ Building } & 0.0503 & -0.1032 & -0.2240 & -0.9061 & -0.2311 \\
\hline & $(0.18)$ & $(-0.35)$ & $(-0.44)$ & $(-1.83)$ & $(-0.41)$ \\
\hline \multirow[t]{2}{*}{ Age } & -0.0054 & -0.0055 & -0.0093 & -0.0232 & -0.0106 \\
\hline & $(-1.83)$ & $(-1.60)$ & $(-2.30)$ & $(-3.61)$ & $(-1.64)$ \\
\hline \multirow[t]{2}{*}{ Agemiss } & -0.2234 & 0.6236 & & 0.1921 & 0.3899 \\
\hline & $(-0.76)$ & (1.69) & & $(0.28)$ & $(0.74)$ \\
\hline \multirow[t]{2}{*}{ Employed } & 5.1247 & -4.2365 & & 7.3864 & 5.0060 \\
\hline & $(2.68)$ & $(-2.47)$ & & $(5.27)$ & (2.69) \\
\hline \multirow[t]{2}{*}{ Poverty } & 1.2684 & -2.6496 & & 0.7277 & -2.0922 \\
\hline & $(1.30)$ & $(-3.22)$ & & $(0.93)$ & $(-3.31)$ \\
\hline \multirow[t]{2}{*}{ Hhinc } & $1.8 \mathrm{E}-06$ & $1.7 \mathrm{E}-05$ & 0.0001 & $2.2 \mathrm{E}-05$ & $-9.6 \mathrm{E}-06$ \\
\hline & $(1.45)$ & $(1.58)$ & $(2.05)$ & $(2.30)$ & $(-1.44)$ \\
\hline \multirow[t]{2}{*}{ Commercial } & -0.4173 & -2.5316 & 2.7188 & -0.0582 & -1.3823 \\
\hline & $(-1.60)$ & $(-15.93)$ & $(1.23)$ & $(-0.40)$ & $(-10.40)$ \\
\hline \multirow[t]{2}{*}{ Industrial } & -0.2661 & -1.5022 & 3.0859 & 0.2425 & -0.6020 \\
\hline & $(-0.83)$ & $(-5.67)$ & $(1.35)$ & $(0.38)$ & $(-2.73)$ \\
\hline \multirow[t]{2}{*}{ Offices } & -0.5586 & -2.6432 & 2.6474 & 0.2075 & -1.0968 \\
\hline & $(-1.69)$ & $(-12.59)$ & $(1.21)$ & $(1.38)$ & $(-6.55)$ \\
\hline \multirow[t]{2}{*}{ LCBD_dist } & -0.4473 & -0.1217 & 0.1220 & -0.9467 & -0.0159 \\
\hline & $(-4.47)$ & $(-1.99)$ & $(0.63)$ & $(-6.56)$ & $(-0.10)$ \\
\hline \multirow[t]{2}{*}{ LCER_dist } & 0.0949 & -0.0400 & 0.2726 & & -0.0294 \\
\hline & $(1.40)$ & $(-0.74)$ & $(1.43)$ & & $(-1.19)$ \\
\hline \multirow[t]{2}{*}{ LNFR_dist } & 0.0025 & -0.0439 & -0.1380 & 0.3238 & -0.0459 \\
\hline & $(0.04)$ & $(-0.95)$ & $(-1.62)$ & $(3.37)$ & $(-1.90)$ \\
\hline \multirow[t]{2}{*}{ NUM_500 } & -0.0388 & & & -0.1151 & 0.1126 \\
\hline & $(-1.49)$ & & & $(-2.84)$ & $(1.12)$ \\
\hline \multirow[t]{2}{*}{ EMP } & -0.1915 & 0.0498 & -0.6092 & 0.6600 & 0.3263 \\
\hline & $(-0.98)$ & $(0.33)$ & $(-1.64)$ & $(3.21)$ & $(0.72)$ \\
\hline \multirow[t]{2}{*}{ ENZ } & -0.1276 & 0.1292 & & -0.5847 & 0.1905 \\
\hline & $(-0.75)$ & $(0.94)$ & & $(-5.15)$ & $(1.53)$ \\
\hline Obs & 540 & 858 & 117 & 1108 & 1032 \\
\hline F Value & 19.08 & 44.87 & 16.16 & 88.14 & 15.39 \\
\hline Adj. R2 & 0.36318 & 0.45 & 0.63 & 0.57 & 0.2 \\
\hline F test: LCER_dist $=$ LNFRdist & 10.6308 & 0.02 & 13.28 & & 1.01 \\
\hline F test: LCER_dist $=$ LNFRdist $=0$ & 5.32 & 0.52 & 6.94 & & 1.93 \\
\hline
\end{tabular}

*Apartments is the default category for land use that has not been included in the regressions. 
Figure 1. Baltimore City

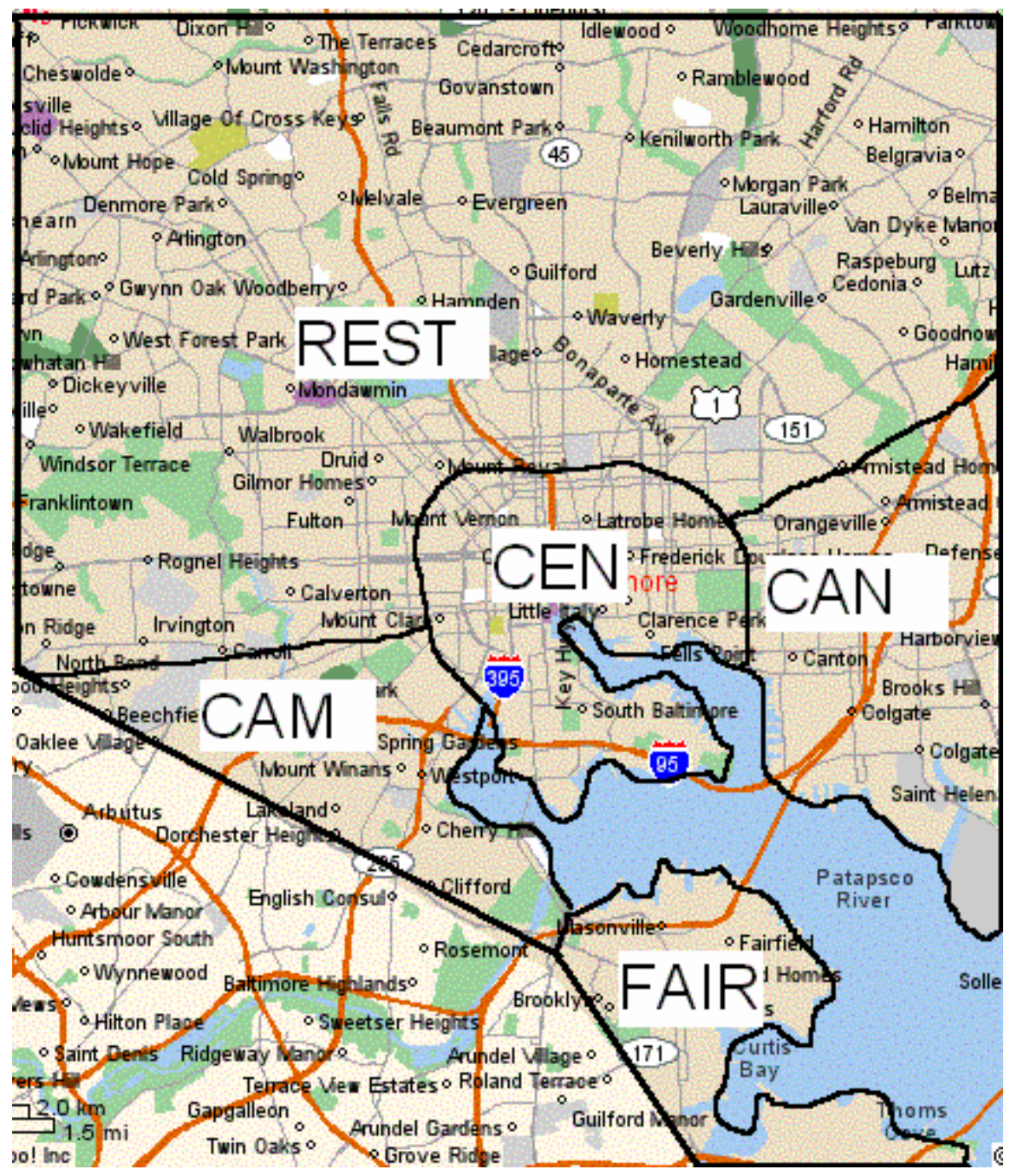

$\mathrm{CEN}=$ Center of Baltimore

$\mathrm{CAN}=$ Canton/Southeast

$\mathrm{CAM}=$ Camden

FAIR $=$ Fairfield

REST $=$ Rest (Periphery) of Baltimore 
Figure 2. Contaminated and potentially contaminated sites in Baltimore City

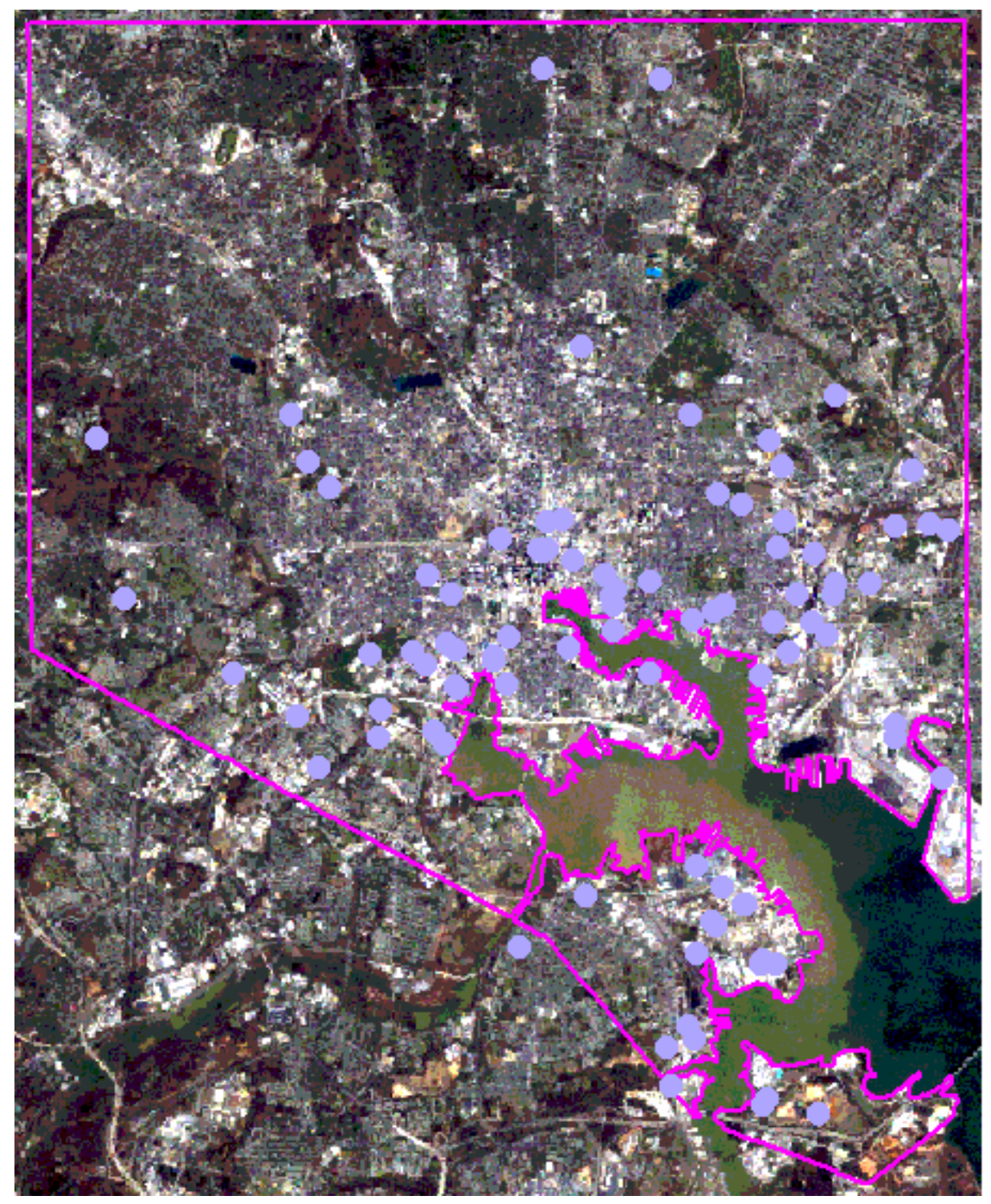


Figure 3 Baltimore City, Enterprise Zones

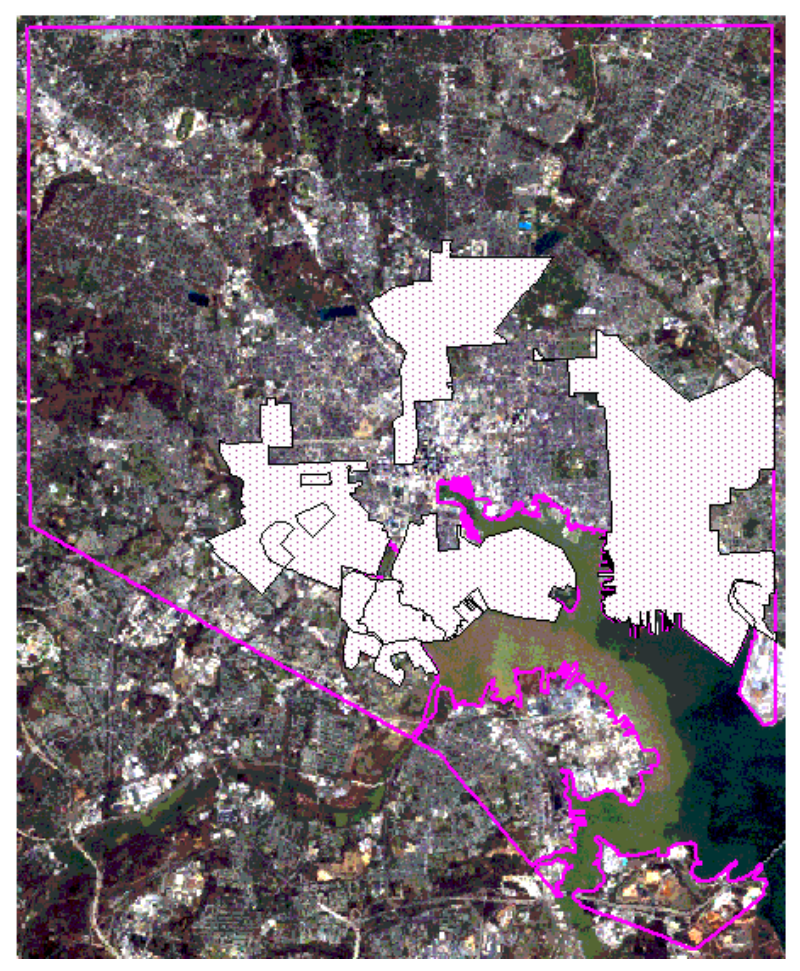

Figure 4. Baltimore City, Empowerment Zones

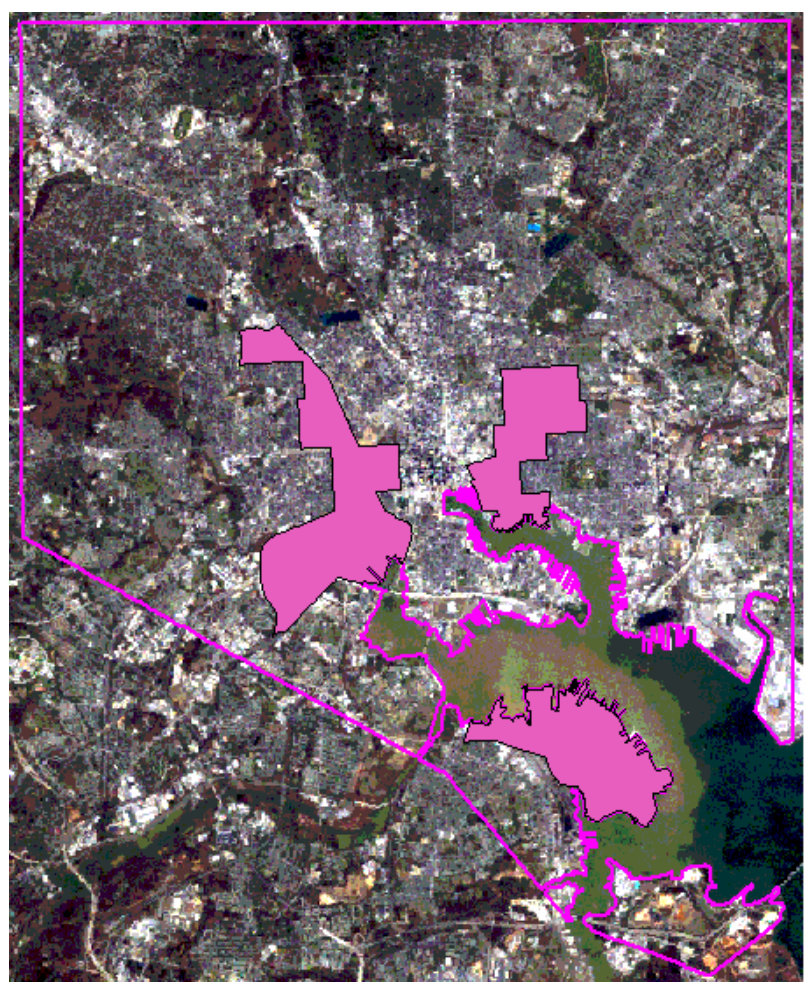

